\title{
Correction: The distributional impact of taxing sugar- sweetened beverages: findings from an extended cost- effectiveness analysis in South Africa
}

Saxena A, Stacey N, Puech PDR, et al. The distributional impact of taxing sugar-sweetened beverages: findings from an extended cost-effectiveness analysis in South Africa. BMJ Global Health 2019;4:e001317. doi: 10.1136/bmjgh-2018-001317

The published version misspelled co-author's name as Paula Del Ray Puech. The correct name should be Paula del Rey Puech.

Open access This is an open access article distributed in accordance with the Creative Commons Attribution Non Commercial (CC BY-NC 4.0) license, which permits others to distribute, remix, adapt, build upon this work non-commercially, and license their derivative works on different terms, provided the original work is properly cited, appropriate credit is given, any changes made indicated, and the use is non-commercial. See: http://creativecommons.org/licenses/by-nc/4.0/.

(C) Author(s) (or their employer(s)) 2019. Re-use permitted under CC BY-NC. No commercial re-use. See rights and permissions. Published by BMJ.

BMJ Global Health 2019;4:e001317corr1. doi:10.1136/bmjgh-2018-001317corr1

(A) Check for updates 